\title{
Thermodynamic Model For Ternary Silicate Systems
}

\author{
Juliana GUTIERREZ, Antonio ROMERO-SERRANO, Gabriel PLASCENCIA, Federico CHAVEZ and \\ Roberto VARGAS
}

Metallurgy and Materials Department, Instituto Politecnico Nacional-ESIQIE, Apdo. P. 75-874, Mexico D.F., 07300.

(Received on January 11, 2000; accepted in final form on March 26, 2000)

\begin{abstract}
A thermodynamic model has been developed for the representation of ternary liquid silicate systems $\mathrm{SiO}_{2}-\mathrm{AO}-\mathrm{BO}$, where $\mathrm{A}$ and $\mathrm{B}$ are metals such as $\mathrm{Ca}, \mathrm{Fe}, \mathrm{Mn}$, etc. It is based on a structural model which assumes that each metallic oxide produces the depolymerization reaction $\mathrm{O}^{\circ}+\mathrm{O}^{2-}=2 \mathrm{O}^{-}$with a characteristic free energy change. The model can calculate the properties of ternary systems solely from data of the binary sub-systems. No ternary terms are required.

The model is used to calculate the activities of the components in complex silicates such as $\mathrm{SiO}_{2}-\mathrm{FeO}-$ $\mathrm{CaO}$ where the behavior of $\mathrm{Fe}^{2+}$ is very different from that of $\mathrm{Ca}^{2+}$ in the silicate structure. This model has been also used to calculate the activities in the systems $\mathrm{SiO}_{2}-\mathrm{MgO}-\mathrm{FeO}, \mathrm{SiO}_{2}-\mathrm{MgO}-\mathrm{CaO}, \mathrm{SiO}_{2}-\mathrm{MgO}-$ $\mathrm{MnO}, \mathrm{SiO}_{2}-\mathrm{Na}-\mathrm{O}-\mathrm{MgO}$ and $\mathrm{SiO}_{2}-\mathrm{Na}_{2} \mathrm{O}-\mathrm{CaO}$. Good agreement is obtained between calculated and experimental results.
\end{abstract}

KEY WORDS: molten silicates, ternary systems, thermodynamic model.

\section{Introduction}

In recent years, the structural model developed by Lin and Pelton ${ }^{1)}$ for silicate systems $\mathrm{MO}-\mathrm{SiO}_{2}(\mathrm{M}=\mathrm{Ca}, \mathrm{Mn}$, $\mathrm{Mg}, \mathrm{Fe}$, etc.) was examined in more depth for binary systems. ${ }^{2)}$ A more general empirical expression for enthalpy was written, and an empirical nonconfigurational excess entropy was added. It was also shown that the structural model can be used to predict sulfide capacities of the melts. ${ }^{3)}$ This model is based on the depolymerization reaction of $\mathrm{SiO}_{2}$ :

$$
\mathrm{M}^{2+} \mathrm{O}^{2-}+\mathrm{Si}-\mathrm{O}-\mathrm{Si}=\mathrm{Si}-\mathrm{O} \quad \mathrm{M}^{2+} \mathrm{O}-\mathrm{Si}
$$

or, in shorthand notation:

$$
\mathrm{O}^{2-}+\mathrm{O}^{\circ}=2 \mathrm{O}^{-}
$$

where $\mathrm{O}^{2-}$ is a free oxygen ion, $\mathrm{O}^{\circ}$ is a bridge oxygen bonded to two silicon atoms, and $\mathrm{O}^{-}$is an oxygen singly bonded to one silicon atom.

The earlier structural model for binary silicate melts was extended to ternary systems $\mathrm{SiO}_{2}-\mathrm{AO}-\mathrm{BO}$ assuming that random mixing of cations $\mathrm{A}^{2+}$ and $\mathrm{B}^{2+}$ occurs when the oxides $\mathrm{AO}$ and $\mathrm{BO}$ behave in a similar way with silicate. ${ }^{4)}$ If the $\mathrm{AO}-\mathrm{SiO}_{2}$ and $\mathrm{BO}-\mathrm{SiO}_{2}$ binary systems exhibit similar thermodynamic behavior, that is comparable free energies of mixing, the properties of the ternary $\mathrm{SiO}_{2}-\mathrm{AO}-\mathrm{BO}$ can be extrapolated from those binary systems in a straightforward fashion. This condition is found in the $\mathrm{SiO}_{2}-\mathrm{MnO}-$ $\mathrm{MgO}$ and $\mathrm{SiO}_{2}-\mathrm{FeO}-\mathrm{MnO}$ systems where the activities and liquidus temperatures calculated solely from data on the binary sub-systems are in good agreement with measured ternary data.
In binary silicate systems, $\mathrm{AO}-\mathrm{SiO}_{2}$ and $\mathrm{BO}-\mathrm{SiO}_{2}$, with very different mixing free energy, the oxides $\mathrm{AO}$ and $\mathrm{BO}$ would behave in a very different way with silicate. For example, the free energies of the $\mathrm{FeO}-\mathrm{SiO}_{2}$ system are very far from those of $\mathrm{CaO}-\mathrm{SiO}_{2}$. This means that $\mathrm{Ca}^{2+}$ and $\mathrm{Fe}^{2+}$ must play a different role in the silicate network. The cations $\mathrm{Ca}^{2+}$ will be found associated to the $\mathrm{O}^{-}$especies and the cations $\mathrm{Fe}^{2+}$ will be close to the free oxygen ions $\mathrm{O}^{2-}$. In this case, the random mixing can not be longer be assumed and the previously developed model $^{4)}$ for ternary systems would fail.

The aim of the present article is to develope a model for ternary silicates systems $\mathrm{SiO}_{2}-\mathrm{AO}-\mathrm{BO}$, where $\mathrm{A}$ and $\mathrm{B}$ are metals such as $\mathrm{Ca}, \mathrm{Fe}, \mathrm{Mn}$, etc., which takes into account the different behavior of the cations in the silicate structure.

\section{Binary Equations}

A detailed development was given previously. ${ }^{2)}$ Only a brief summary will be presented here. The structural model assumes that every silicon atom is bonded to four oxygen atoms. Thus, mass balance considerations require that:

$$
\begin{aligned}
& N_{\mathrm{o}^{\circ}}=2 X_{\mathrm{SiO}_{2}}-\frac{N_{\mathrm{O}^{-}}}{2} \\
& N_{\mathrm{O}^{2-}}=X_{\mathrm{MO}}-\frac{N_{\mathrm{O}^{-}}}{2}
\end{aligned}
$$

where $X_{\mathrm{MO}}$ and $X_{\mathrm{SiO}_{2}}$ are the mole fractions of the components and $N_{\mathrm{O}^{\circ}}, N_{\mathrm{O}^{2-}}$ and $N_{\mathrm{O}^{-}}$are the numbers of moles of the various oxygen species per mole of solution. The configurational entropy is calculated by assuming a tetrahedral quasi lattice in which the sites are occupied by $\mathrm{O}^{2-}$ ions and $\mathrm{Si}$ 
atoms (each associated with four oxygen atoms bonded to it):

$$
\begin{aligned}
\Delta S^{\mathrm{C}}= & -R\left[X_{\mathrm{SiO}_{2}} \ln \left(\frac{X_{\mathrm{SiO}_{2}}}{X_{\mathrm{SiO}_{2}}+N_{\mathrm{O}^{2-}}}\right)+N_{\mathrm{O}^{2-}} \ln \left(\frac{N_{\mathrm{O}^{2-}}}{X_{\mathrm{SiO}_{2}}+N_{\mathrm{O}^{2-}}}\right)\right] \\
& -R\left[N_{\mathrm{O}^{\circ}} \ln \left(\frac{N_{\mathrm{O}^{\circ}}}{N_{\mathrm{Si}-\mathrm{Si}}}\right)+\left(N_{\mathrm{Si}-\mathrm{Si}}-N_{\mathrm{O}^{\circ}}\right) \ln \left(\frac{N_{\mathrm{Si}-\mathrm{Si}}-N_{\mathrm{O}^{\circ}}}{N_{\mathrm{Si}-\mathrm{Si}}}\right)\right]
\end{aligned}
$$

where $N_{\mathrm{Si}-\mathrm{Si}}$ is the number of moles of neighboring $\mathrm{Si}-\mathrm{Si}$ pairs per mole of solution:

$$
N_{\mathrm{Si}-\mathrm{Si}}=\frac{4 X_{\mathrm{SiO}_{2}}}{2}\left(\frac{X_{\mathrm{SiO}_{2}}}{X_{\mathrm{SiO}_{2}}+N_{\mathrm{O}^{2-}}}\right)
$$

The structural model assumes that Reaction (1) is associated with a Gibbs energy change containing an enthalpic $(\omega)$ and entropic $(\eta)$ term:

$$
\begin{aligned}
& \Delta H=\left(\frac{N_{\mathrm{O}^{-}}}{2}\right) \omega \\
& S^{\mathrm{nc}}=\left(\frac{N_{\mathrm{O}^{-}}}{2}\right) \eta
\end{aligned}
$$

Finally, $\omega$ and $\eta$ are expanded as polynomials:

$$
\begin{gathered}
\omega=\omega_{0}+\omega 1 X_{\mathrm{SiO}_{2}}+\omega_{2} X_{\mathrm{SiO}_{2}}^{2}+\ldots \\
\eta=\eta_{0}+\eta 1 X_{\mathrm{SiO}_{2}}+\eta_{2} X_{\mathrm{SiO}_{2}}^{2}+\ldots
\end{gathered}
$$

The coefficients $\omega_{i}$ and $\eta_{i}$ are the parameters of the model which are obtained by optimization of the data. Given a composition, $X_{\mathrm{SiO}_{2}}$, and values of the parameters $\omega_{\mathrm{i}}$ and $\eta_{\mathrm{i}}$, the actual value of $N_{\mathrm{O}^{-}}$can be calculated by minimizing the Gibbs energy at constant $X_{\mathrm{SiO}_{2}}, \omega$ and $\eta$ :

$$
\Delta G=\Delta H-T\left(\Delta S^{\mathrm{c}}+S^{\mathrm{nc}}\right)
$$

$$
\begin{aligned}
& 2\left[\frac{\partial \Delta G}{\partial N_{\mathrm{O}^{-}}}\right]_{X_{\mathrm{Si}_{2},}, \omega, \eta} \\
&=(\omega-\eta T)-R T\left[\ln \left(\frac{N_{\mathrm{O}^{2-}}}{1-X_{\mathrm{MO}}+N_{\mathrm{O}^{2-}}}\right)+\left(\frac{N_{\mathrm{O}^{\circ}}}{N_{\mathrm{Si}-\mathrm{Si}}}\right)\right. \\
&\left.-\left(1+\frac{N_{\mathrm{Si}-\mathrm{Si}}}{1-X_{\mathrm{MO}}+N_{\mathrm{O}^{2-}}}\right) \ln \left(\frac{N_{\mathrm{Si}-\mathrm{Si}}-N_{\mathrm{O}^{\circ}}}{N_{\mathrm{Si}-\mathrm{Si}}}\right)\right]=0
\end{aligned}
$$

Substitution of Eqs. (3), (4) and (6) into Eq. (12) gives an equation in terms of $X_{\mathrm{MO}}\left(\right.$ or $\left.X_{\mathrm{SiO}_{2}}\right)$ and $N_{\mathrm{O}^{-}}$, which can be solved numerically at a fixed composition and for given values of the parameters $\omega_{i}$ and $\eta_{i}$ to give $N_{\mathrm{O}^{-}}$. This value can then be substituted back into Eqs. (3), (4), (5), (7) and (8) to give $\Delta S$ and $\Delta H$.

\section{Binary Metallic Oxide Systems}

The main goal of this paper is to apply the model to analyse $\mathrm{SiO}_{2}-\mathrm{AO}-\mathrm{BO}$ ternary systems. Thus, a model is necessary to represent the thermodynamic properties of the liquid binary metallic oxides (AO-BO). In this work the following expression was chosen:

$$
\begin{aligned}
& G_{\mathrm{AO}-\mathrm{BO}}^{\mathrm{E}}=X_{\mathrm{AO}} X_{\mathrm{BO}}\left[\left(a_{1}+a_{2} T\right)+\left(b_{1}+b_{2} T\right) X_{\mathrm{BO}}+\right. \\
& \left(c_{1}+c_{2} T\right) \mathrm{X}_{\mathrm{BO}}^{2}
\end{aligned}
$$

where $a_{i}, b_{i}$ and $c_{i}$ are constant parameters.

\section{Ternary Equations}

Let us consider the general $\mathrm{SiO}_{2}-\mathrm{AO}-\mathrm{BO}$ ternary system where $\mathrm{A}$ and $\mathrm{B}$ are divalent cations. It is assumed that there are 5 kind of oxygens:

1. $\mathrm{O}^{\circ}$ : Bridge oxygens

2. $\mathrm{O}_{\mathrm{A}}^{2-}$ : "Free oxygens ions" introduced in the system by the $\mathrm{AO}$ species

3. $\mathrm{O}_{\mathrm{B}}^{2-}$ : "Free oxygens ions" introduced in the system by the BO species

4. $\mathrm{O}_{\mathrm{A}}^{-}$: Broken bridges for the AO species

5. $\mathrm{O}_{\mathrm{B}}^{-}$: Broken bridges for the $\mathrm{BO}$ species

That is, there are two depolymerization reactions given by:

$$
\begin{gathered}
\mathrm{Si}-\mathrm{O}-\mathrm{Si}+\mathrm{AO}=\mathrm{Si}-\mathrm{O} \quad \mathrm{O}-\mathrm{Si} \quad(\omega-\eta T)_{\mathrm{AO}} \\
\mathrm{B} \\
\mathrm{Si}-\mathrm{O}-\mathrm{Si}+\mathrm{BO}=\mathrm{Si}-\mathrm{O} \quad \mathrm{O}-\mathrm{Si} \quad(\omega-\eta T)_{\mathrm{BO}}
\end{gathered}
$$

The mass balance considerations requires now that:

$$
\begin{aligned}
& N_{\mathrm{O}^{\circ}}=2 X_{\mathrm{SiO}_{2}}-\frac{N_{\mathrm{O}_{\mathrm{A}}^{-}}+N_{\mathrm{O}_{\mathrm{B}}^{-}}}{2} \\
& N_{\mathrm{O}_{\mathrm{A}}^{2-}}=X_{\mathrm{AO}}-\frac{N_{\mathrm{O}_{\mathrm{A}}^{-}}}{2} \\
& N_{\mathrm{O}_{\mathrm{B}}^{2-}}=X_{\mathrm{BO}}-\frac{N_{\mathrm{O}_{\mathrm{B}}^{-}}}{2}
\end{aligned}
$$

Combination of Eqs. (17) and (18) gives:

$$
N_{\mathrm{O}_{\mathrm{A}}^{2-}}+N_{\mathrm{O}_{\mathrm{B}}^{2-}}=\left(X_{\mathrm{AO}}+X_{\mathrm{BO}}\right)-\frac{N_{\mathrm{O}_{\mathrm{A}}^{-}}+N_{\mathrm{O}_{\mathrm{B}}^{-}}}{2}
$$

The number of moles of neighboring $\mathrm{Si}-\mathrm{Si}$ pairs per mole of solution $\left(N_{\mathrm{Si}-\mathrm{Si}}\right)$ in the ternary system is expressed by:

$$
N_{\mathrm{Si}-\mathrm{Si}}=\frac{4 X_{\mathrm{SiO}_{2}}}{2}\left(\frac{X_{\mathrm{SiO}_{2}}}{X_{\mathrm{SiO}_{2}}+N_{\mathrm{O}_{\mathrm{A}}^{2-}}+N_{\mathrm{O}_{\mathrm{B}}^{2-}}}\right)
$$

\subsection{Configurational Entropy}

The expression of the entropy is obtained making two statistical distributions:

$$
S^{\mathrm{c}}=S_{\mathrm{I}}^{\mathrm{c}}+S_{\mathrm{II}}^{\mathrm{c}}
$$

Where $S_{\mathrm{I}}^{\mathrm{c}}$ is estimated through the distribution of $\mathrm{O}_{\mathrm{A}}^{2-}, \mathrm{O}_{\mathrm{B}}^{2-}$ and $\mathrm{Si}$ in a quasilattice:

$$
\begin{aligned}
S_{\mathrm{I}}^{\mathrm{c}}= & -R\left\{N_{\mathrm{O}_{\mathrm{A}}^{2-}} \ln \left(\frac{N_{\mathrm{O}_{\mathrm{A}}^{2-}}}{N_{\mathrm{O}_{\mathrm{A}}^{2-}}+N_{\mathrm{O}_{\mathrm{B}}^{2-}}+X_{\mathrm{SiO}_{2}}}\right)\right. \\
& +N_{\mathrm{O}_{\mathrm{B}}^{2-}} \ln \left(\frac{N_{\mathrm{O}_{\mathrm{B}}^{2-}}}{N_{\mathrm{O}_{\mathrm{A}}^{2-}}+N_{\mathrm{O}_{\mathrm{B}}^{2-}}+X_{\mathrm{SiO}_{2}}}\right)
\end{aligned}
$$




$$
+X_{\mathrm{SiO}_{2}} \ln \left(\frac{X_{\mathrm{SiO}_{2}}}{N_{\mathrm{O}_{\mathrm{A}}^{2-}}+N_{\mathrm{O}_{\mathrm{B}}^{2-}}+X_{\mathrm{SiO}_{2}}}\right)
$$

$S_{\mathrm{II}}^{\mathrm{c}}$ is estimated through the distribution of $\mathrm{O}^{\circ}$ over the neighboring $\mathrm{Si}-\mathrm{Si}$ pairs:

$$
S_{\mathrm{II}}^{\mathrm{c}}=-R\left\{N_{\mathrm{O}^{\circ}} \ln \left(\frac{N_{\mathrm{O}^{\circ}}}{N_{\mathrm{Si}-\mathrm{Si}}}\right)+\left(N_{\mathrm{Si}-\mathrm{Si}}-N_{\mathrm{O}^{\circ}}\right) \ln \left(\frac{N_{\mathrm{Si}-\mathrm{Si}}-N_{\mathrm{O}^{\circ}}}{N_{\mathrm{Si}-\mathrm{Si}}}\right)\right\}
$$

\subsection{Excess Free Energy}

The excess free energy expression for the ternary system is obtained by the addition of the interaction energy terms $(\omega-\eta T)$ for each bridge breaking reaction, Eqs. (14) and (15), which are known in the two binary systems $\left(\mathrm{AO}-\mathrm{SiO}_{2}\right.$ and $\mathrm{BO}-\mathrm{SiO}_{2}$ ) from the binary optimizations. This expression also must include the contribution of the excess free energy for the AO-BO binary system, $G_{\mathrm{AO}-\mathrm{BO}}$, which is multiplied by the fraction of free oxygen ions in the quasi lattice whose sites are occupied by $\mathrm{O}^{2-}$ ions and $\mathrm{Si}$ atoms.

$$
\begin{aligned}
G^{\mathrm{E}}= & \frac{N_{\mathrm{O}_{\mathrm{A}}^{-}}}{2}(\omega-\eta T)_{\mathrm{AO}}+\frac{N_{\mathrm{O}_{\mathrm{B}}^{-}}}{2}(\omega-\eta T)_{\mathrm{BO}} \\
& +\left(\frac{N_{\mathrm{O}_{\mathrm{A}}^{2-}}+N_{\mathrm{O}_{\mathrm{B}}^{2-}}}{N_{\mathrm{O}_{\mathrm{A}}^{2-}}+N_{\mathrm{O}_{\mathrm{B}}^{2-}}+X_{\mathrm{SiO}_{2}}}\right) G_{\mathrm{AO}-\mathrm{BO}}^{\mathrm{E}} \cdots \cdots . . . . . .
\end{aligned}
$$

The Gibbs free energy of mixing is then obtained joining the expressions (22) to (24)

$$
\begin{aligned}
\Delta g^{\mathrm{mix}}= & R T\left\{N_{\mathrm{O}_{\mathrm{A}}^{2-}} \ln \left(\frac{N_{\mathrm{O}_{\mathrm{A}}^{2-}}}{N_{\mathrm{O}_{\mathrm{A}}^{2-}}+N_{\mathrm{O}_{\mathrm{B}}^{2-}}+X_{\mathrm{SiO}_{2}}}\right)\right. \\
& +N_{\mathrm{O}_{\mathrm{B}}^{2-}} \ln \left(\frac{N_{\mathrm{O}_{\mathrm{B}}^{2-}}}{N_{\mathrm{O}_{\mathrm{A}}^{2-}}+N_{\mathrm{O}_{\mathrm{B}}^{2-}}+X_{\mathrm{SiO}_{2}}}\right) \\
& +X_{\mathrm{SiO}_{2}} \ln \left(\frac{X_{\mathrm{SiO}_{2}}}{N_{\mathrm{O}_{\mathrm{A}}^{2-}}+N_{\mathrm{O}_{\mathrm{B}}^{2-}}+X_{\mathrm{SiO}_{2}}}\right)+N_{\mathrm{O}^{\circ}} \ln \left(\frac{N_{\mathrm{O}^{\circ}}}{N_{\mathrm{Si}-\mathrm{Si}}}\right) \\
& \left.+\left(N_{\mathrm{Si}_{-} \mathrm{Si}}-N_{\mathrm{O}^{\circ}}\right) \ln \left(\frac{N_{\mathrm{Si}_{-} \mathrm{Si}}-N_{\mathrm{O}^{\circ}}}{N_{\mathrm{Si}_{-} \mathrm{Si}}}\right)\right\}+\frac{N_{\mathrm{O}_{\mathrm{A}}^{-}}}{2}(\omega-\eta T)_{\mathrm{AO}} \\
& +\frac{N_{\mathrm{O}_{\mathrm{B}}^{-}}}{2}(\omega-\eta T)_{\mathrm{BO}}+\left(\frac{N_{\mathrm{O}_{\mathrm{A}}^{2-}}+N_{\mathrm{O}_{\mathrm{B}}^{2-}}}{N_{\mathrm{O}_{\mathrm{A}}^{2-}}+N_{\mathrm{O}_{\mathrm{B}}^{2-}}+X_{\mathrm{SiO}_{2}}}\right) G_{\mathrm{AO}-\mathrm{BO}}^{\mathrm{E}}
\end{aligned}
$$

This expression is thermodynamically consistent with the Gibbs-Duhem and Gibbs-Helmholtz equations. Equation (25) reduces to the respective expressions for the binary sub-systems:

a) If $X_{\mathrm{AO}}=0$ or $X_{\mathrm{BO}}=0$

$$
\Delta g^{\mathrm{mix}}=R T\left\{N_{\mathrm{O}^{2-}} \ln \left(\frac{N_{\mathrm{O}^{2-}}}{N_{\mathrm{O}^{2-}}+X_{\mathrm{SiO}_{2}}}\right)\right.
$$

$$
\begin{aligned}
& +X_{\mathrm{SiO}_{2}} \ln \left(\frac{X_{\mathrm{SiO}_{2}}}{N_{\mathrm{O}^{2-}}+X_{\mathrm{SiO}_{2}}}\right)+N_{\mathrm{O}^{\circ}} \ln \left(\frac{N_{\mathrm{O}^{\circ}}}{N_{\mathrm{Si}-\mathrm{Si}}}\right) \\
& \left.+\left(N_{\mathrm{Si}-\mathrm{Si}}-N_{\mathrm{O}^{\circ}}\right) \ln \left(\frac{N_{\mathrm{Si}-\mathrm{Si}}-N_{\mathrm{O}^{\circ}}}{N_{\mathrm{Si}-\mathrm{Si}}}\right)\right\}+\frac{N_{\mathrm{O}^{-}}}{2}(\omega-\eta T)
\end{aligned}
$$

b) If $X_{\mathrm{SiO}_{2}}=0$

$$
\begin{aligned}
& N_{\mathrm{O}_{\mathrm{A}}^{2-}}=X_{\mathrm{AO}}, N_{\mathrm{O}_{\mathrm{B}}^{2-}}=X_{\mathrm{BO}}, \text { and } \\
& \Delta g^{\operatorname{mix}}=R T\left[X_{\mathrm{AO}} \ln \left(X_{\mathrm{AO}}\right)+X_{\mathrm{BO}} \ln \left(X_{\mathrm{BO}}\right)\right]+G_{\mathrm{AO}-\mathrm{BO}}^{\mathrm{E}}
\end{aligned}
$$

The expression of $\Delta g^{\text {mix }}$ depends on two parameters $\left(N_{\mathrm{O}_{\mathrm{A}}^{2-}}\right.$ and $N_{\mathrm{O}_{\mathrm{B}}^{2-}}$ or $N_{\mathrm{O}_{\mathrm{A}}^{-}}$and $N_{\mathrm{O}_{\mathrm{B}}^{-}}$). Their values will be calculated by minimizing the expression of the free energy. Choosing the first pair of parameters one obtains:

$$
\begin{aligned}
& \left(\frac{\partial \Delta g^{m i x}}{\partial N_{\mathrm{O}_{\mathrm{A}}^{2-}}}\right)_{X_{\mathrm{SiO}_{2}}, X_{\mathrm{BO}}, N_{\mathrm{O}_{\mathrm{B}}^{2-}}} \\
& \left(\frac{\partial \Delta g^{\mathrm{mix}}}{\partial N_{\mathrm{O}_{\mathrm{B}}^{2-}}}\right)_{X_{\mathrm{SiO}_{2}}, X_{\mathrm{AO}}, N_{\mathrm{O}_{\mathrm{A}}^{2-}}}
\end{aligned}
$$

Minimizing $\Delta g^{\text {mix }}$ with respect to $N_{\mathrm{O}_{\mathrm{A}}^{-}}$one obtains:

$$
\begin{aligned}
\frac{\partial \Delta g^{\text {mix }}}{\partial N_{\mathrm{O}_{\mathrm{A}}^{2-}}}= & R T\left\{\ln \left(\frac{N_{\mathrm{O}_{\mathrm{A}}^{2-}}}{N_{\mathrm{O}_{\mathrm{A}}^{2-}}+N_{\mathrm{O}_{\mathrm{B}}^{2-}}+X_{\mathrm{SiO}_{2}}}\right) \ln +\left(\frac{N_{\mathrm{O}^{\circ}}}{N_{\mathrm{Si}-\mathrm{Si}}}\right)\right. \\
& \left.+\left(\frac{\partial N_{\mathrm{Si}-\mathrm{Si}}}{\partial N_{\mathrm{O}_{\mathrm{A}}^{2-}}}-1\right) \ln \left(\frac{N_{\mathrm{Si}-\mathrm{Si}}-N_{\mathrm{O}^{\circ}}}{N_{\mathrm{Si}-\mathrm{Si}}}\right)\right\} \\
& -(\omega-\eta T)_{\mathrm{AO}}+\left(\frac{X_{\mathrm{SiO}_{2}}}{\left(N_{\mathrm{O}_{\mathrm{A}}^{2-}}+N_{\mathrm{O}_{\mathrm{B}}^{2-}}+X_{\mathrm{SiO}_{2}}\right)^{2}}\right) G_{\mathrm{AO}-\mathrm{BO}}^{\mathrm{E}}
\end{aligned}
$$

where

$$
\frac{\partial N_{\mathrm{Si}-\mathrm{Si}}}{\partial N_{\mathrm{O}_{\mathrm{A}}^{2-}}}=\frac{-2\left(X_{\mathrm{SiO}_{2}}\right)^{2}}{\left(N_{\mathrm{O}_{\mathrm{A}}^{2-}}+N_{\mathrm{O}_{\mathrm{B}}^{2-}}+X_{\mathrm{SiO}_{2}}\right)^{2}}
$$

Now minimizing $\Delta g^{\text {mix }}$ with respect to $N_{\mathrm{O}_{\mathrm{B}}^{2-}}$ one obtains:

$$
\begin{aligned}
\frac{\partial \Delta g^{\text {mix }}}{\partial N_{\mathrm{O}_{\mathrm{B}}^{2-}}}= & R T\left\{\ln \left(\frac{N_{\mathrm{O}_{\mathrm{B}}^{2-}}}{N_{\mathrm{O}_{\mathrm{A}}^{2-}}+N_{\mathrm{O}_{\mathrm{B}}^{2-}}+X_{\mathrm{SiO}_{2}}}\right)+\ln \left(\frac{N_{\mathrm{O}^{\circ}}}{N_{\mathrm{Si}-\mathrm{Si}}}\right)\right. \\
& \left.+\left(\frac{\partial N_{\mathrm{Si}-\mathrm{Si}}}{\partial N_{\mathrm{O}_{\mathrm{B}}^{2-}}}-1\right) \ln \left(\frac{N_{\mathrm{Si}-\mathrm{Si}}-N_{\mathrm{O}^{\circ}}}{N_{\mathrm{Si}-\mathrm{Si}}}\right)\right\} \\
& -(\omega-\eta T)_{\mathrm{BO}}+\left(\frac{X_{\mathrm{SiO}_{2}}}{\left(N_{\mathrm{O}_{\mathrm{A}}^{2-}}+N_{\mathrm{O}_{\mathrm{B}}^{2-}}+X_{\mathrm{SiO}_{2}}\right)^{2}}\right) G_{\mathrm{AO}-\mathrm{BO}}^{\mathrm{E}}
\end{aligned}
$$

where

$$
\frac{\partial N_{\mathrm{Si}-\mathrm{Si}}}{\partial N_{\mathrm{O}_{\mathrm{B}}^{2-}}}=\frac{-2\left(X_{\mathrm{SiO}_{2}}\right)^{2}}{\left(N_{\mathrm{O}_{\mathrm{A}}^{2-}}+N_{\mathrm{O}_{\mathrm{B}}^{2-}}+X_{\mathrm{SiO}_{2}}\right)^{2}}
$$


Table 1. Energy parameters, $\omega$ and $\eta$, for the bridge breaking reaction in binary silicate systems $\left.{ }^{2}\right)\left(\omega\right.$ in $\mathrm{J} \mathrm{mol}^{-1}$ and $\eta$ in $\mathrm{J} \mathrm{mol}^{-1} \mathrm{~K}^{-1}$ ).

\begin{tabular}{|c|c|}
\hline SYSTEM & $\omega$ and $\eta$ parameters \\
\hline $\mathrm{MnO}-\mathrm{SiO}_{2}$ & $\begin{array}{l}\omega=-56,143-1,791 \mathrm{X}_{\mathrm{SiO}_{2}}+116,820 \mathrm{X}_{\mathrm{SiO}_{2}}^{3} \\
\eta=-15.11+18.638 \mathrm{X}_{\mathrm{SiO}_{2}}^{3}\end{array}$ \\
\hline $\mathrm{MgO}-\mathrm{SiO}_{2}$ & $\begin{array}{l}\omega=-55,140-76,333 \mathrm{X}_{\mathrm{SiO}_{2}}+245,570 \mathrm{X}_{\mathrm{SiO}_{2}}^{3} \\
\eta=-47.99 \mathrm{X}_{\mathrm{SiO}_{2}}+18.638 \mathrm{X}_{\mathrm{SiO}_{2}}^{3}\end{array}$ \\
\hline $\mathrm{FeO}-\mathrm{SiO}_{2}$ & $\begin{array}{l}\omega=6,770-122,724 \mathrm{X}_{\mathrm{SiO}_{2}}+183,040 \mathrm{X}_{\mathrm{SiO}_{2}}^{2}+106,539 \mathrm{X}_{\mathrm{SiO}_{2}}^{4} \\
\eta=-34.59 \mathrm{X}_{\mathrm{SiO}_{2}}+87.366 \mathrm{X}_{\mathrm{SiO}_{2}}^{3}\end{array}$ \\
\hline $\mathrm{CaO}-\mathrm{SiO}_{2}$ & $\begin{array}{l}\omega=-57,738-258,739 \mathrm{X}_{\mathrm{SiO}_{2}}+262,548 \mathrm{X}_{\mathrm{SiO}_{2}}^{2}+89,325 \mathrm{X}_{\mathrm{SiO}_{2}}^{6} \\
\eta=-35.5 \mathrm{X}_{\mathrm{SiO}_{2}}+70.71 \mathrm{X}_{\mathrm{SiO}_{2}}^{4}\end{array}$ \\
\hline $\mathrm{Na}_{2} \mathrm{O}-\mathrm{SiO}{ }_{2}$ & $\begin{array}{l}\omega=-90,841-473,168 \mathrm{X}_{\mathrm{SiO}_{2}}+297,835 \mathrm{X}_{\mathrm{SiO}_{2}}^{2} \\
\eta=-31.38\end{array}$ \\
\hline
\end{tabular}

Since Eqs. (30) and (32) are both equal to zero and given that $\partial N_{\mathrm{Si}-\mathrm{Si}} / \partial N_{\mathrm{O}_{\mathrm{A}}^{2-}}=\partial N_{\mathrm{Si}-\mathrm{Si}} / \partial N_{\mathrm{O}_{\mathrm{B}}^{2-}}$ we can reduce the number of unknowns through the resulting expression:

$$
N_{\mathrm{O}_{\mathrm{A}}^{2-}}=\left(N_{\mathrm{O}_{\mathrm{B}}^{2-}}\right) \exp \left(\frac{-\Delta e}{R T}\right)
$$

where $\Delta e=(\omega-\eta T)_{\mathrm{BO}}-(\omega-\eta T)_{\mathrm{AO}}$.

Thus, it is required to solve only a non-linear equation with one unknown in order to estimate the amount of different kind of oxygens as well as the mixing free energy.

This model is also applied to systems of the type $\mathrm{SiO}_{2}-$ $\mathrm{A}_{2} \mathrm{O}-\mathrm{BO}$, for example $\mathrm{SiO}_{2}-\mathrm{Na}_{2} \mathrm{O}-\mathrm{MgO}$, in the silica rich region. In this case, we assume $\mathrm{A}^{+}$cations associate in pairs and remain so in the silicate structure.

\section{Applications}

The test of the model have been made for the following ternary systems $\mathrm{SiO}_{2}-\mathrm{FeO}-\mathrm{CaO}, \mathrm{SiO}_{2}-\mathrm{FeO}-\mathrm{MgO}, \mathrm{SiO}_{2}-$ $\mathrm{MgO}-\mathrm{CaO}, \mathrm{SiO}_{2}-\mathrm{MnO}-\mathrm{MgO}, \mathrm{SiO}_{2}-\mathrm{Na}_{2} \mathrm{O}-\mathrm{MgO}$ and $\mathrm{SiO}_{2}-$ $\mathrm{Na}_{2} \mathrm{O}-\mathrm{CaO}$. The parameters $\omega_{\mathrm{i}}$ and $\eta_{\mathrm{i}}$ for the binary silicate systems $\mathrm{MO}-\mathrm{SiO}_{2}\left(\mathrm{M}=\mathrm{Fe}, \mathrm{Ca}, \mathrm{Mg}, \mathrm{Mn}, \mathrm{Na}_{2}\right)$ are given in Table $\mathbf{1}^{2)}$ and the parameters of the excess free energy for the binary liquid metallic oxides AO-BO are shown in Table 2.,5)

\section{1. $\mathrm{SiO}_{2}-\mathrm{FeO}-\mathrm{CaO}$}

Activities of $\mathrm{FeO}$ in the liquid phase were determined by Timucin and Morris ${ }^{6)}$ at $1823 \mathrm{~K}$ by equilibration of the melts, held in thin-walled platinum crucibles, with $\mathrm{CO} / \mathrm{CO}_{2}$ mixtures. The experimental and calculated activities of $\mathrm{FeO}$, shown in Fig. 1, are in good agreement, especially between 0.4 and 0.8 .

\section{2. $\mathrm{SiO}_{2}-\mathrm{FeO}-\mathrm{MgO}$}

The calculated curves of activities of $\mathrm{FeO}$ at $1873 \mathrm{~K}$
Table 2. Excess free energy for the liquid binary metallic oxide systems.

$G^{E}=X_{A O} X_{B O}\left[\left(a_{1}+a_{2} T\right)+\left(b_{1}+b_{2} T\right) X_{B O}+\left(c_{1}+c_{2} T\right) X_{B O}{ }^{2}\right] J / m o l$

\begin{tabular}{|c|c|c|c|c|c|}
\hline SYSTEM & $\mathbf{a}_{1}$ & $\mathbf{a}_{2}$ & $\mathbf{b}_{1}$ & $\mathbf{c}_{1}$ & Ref. \\
\hline MgO-MnO & 2810 & 0.0 & 0.0 & 0.0 & 4 \\
\hline CaO-MnO & 15924 & 0.0 & 0.0 & 0.0 & 5 \\
\hline FeO-MnO & 0.0 & 0.0 & 0.0 & 0.0 & 4 \\
\hline MgO-CaO & 24311 & 0.0 & -14490 & 0.0 & 5 \\
\hline MgO-FeO & 7531 & 0.0 & 0.0 & 0.0 & 4 \\
\hline FeO-CaO & -107294 & 41.84 & 0.0 & -17442 & 5 \\
\hline
\end{tabular}

$\mathrm{b}_{2}$ and $\mathrm{c}_{2}$ are equal to zero for all the systems

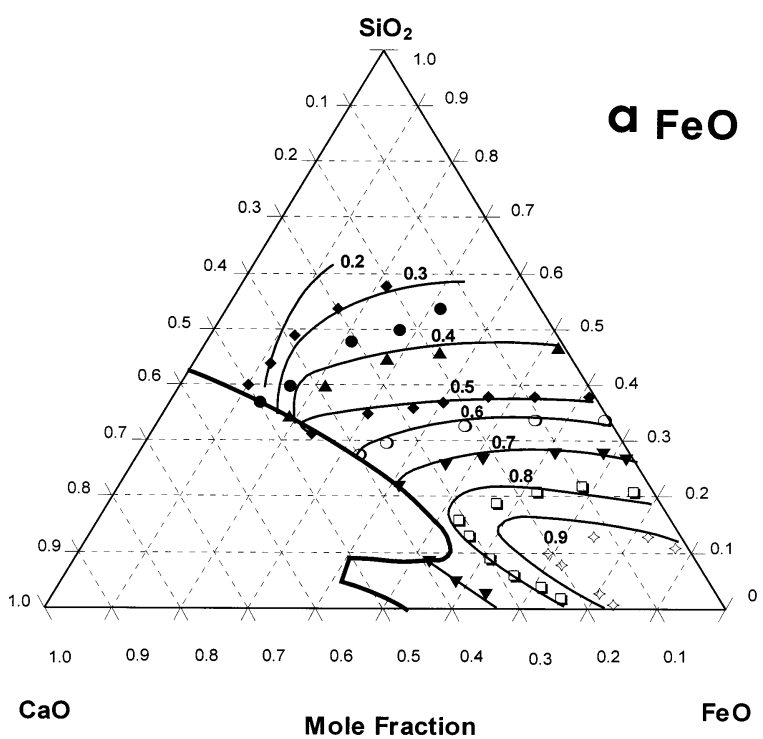

Fig. 1. Calculated and experimental ${ }^{6)}$ iso-activity curves of $\mathrm{FeO}$ at $1823 \mathrm{~K}$ in liquid $\mathrm{SiO}_{2}-\mathrm{FeO}-\mathrm{CaO}$ solution (liquid standard state).

plotted in Fig. 2 are consistent with the concentration dependance of the experimental data obtained by Ban-ya et $a l .{ }^{7)}$ by equilibration of the melts with $\mathrm{H}_{2} / \mathrm{H}_{2} \mathrm{O}$ mixtures.

\section{3. $\mathrm{SiO}_{2}-\mathrm{MgO}-\mathrm{CaO}$}

Activities of $\mathrm{SiO}_{2}$ in the liquid phase (relative to the solid as standard state) were determined by Rein and Chipman ${ }^{8)}$ at $1873 \mathrm{~K}$ by measuring the distribution of $\mathrm{Si}$ between the slag and an $\mathrm{Fe}-\mathrm{Si}-\mathrm{C}$ alloy saturated either with graphite or $\mathrm{SiC}$. The experimental activities of $\mathrm{SiO}_{2}$ are shown in Fig. 3 along with the calculated values by the model. The Gibbs energy of fusion of pure $\mathrm{SiO}_{2}$ was taken as ${ }^{9}$ :

$$
\Delta \mathrm{G}_{\text {fusion }}^{\circ}\left(\mathrm{SiO}_{2}\right)=9581.36-4.8003 T \mathrm{~J} / \mathrm{mol} \text {. }
$$

\section{4. $\mathrm{SiO}_{2}-\mathrm{MnO}-\mathrm{MgO}$}

In Fig. 4 is shown the comparison between calculated activities of $\mathrm{MnO}$ at $1923 \mathrm{~K}$ (relative to the solid as standard state) and the experimental values measured by Metha and Richardson. ${ }^{10)}$ In this experimental work the slags contain- 


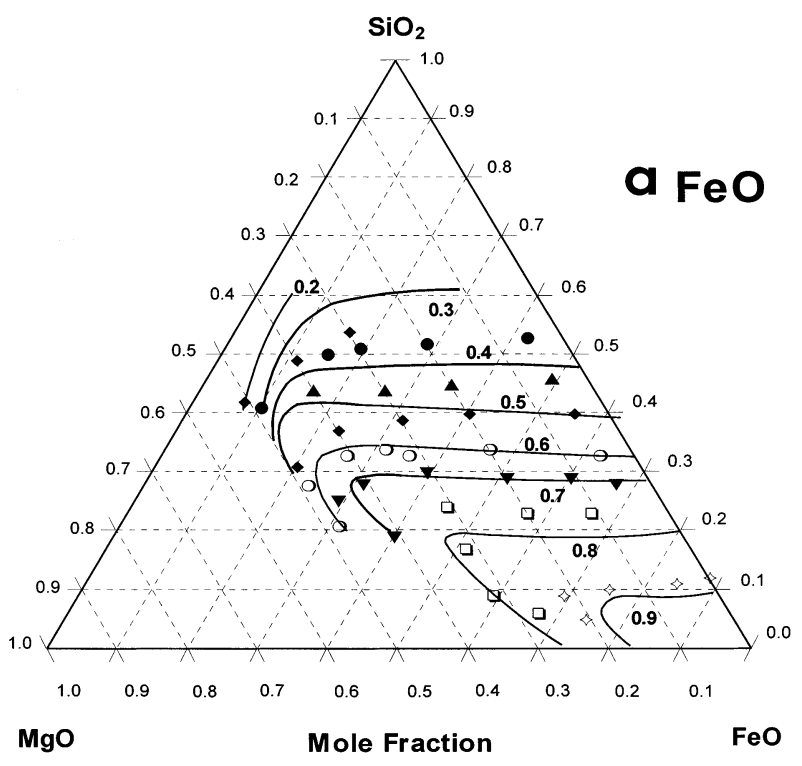

Fig. 2. Calculated and experimental ${ }^{7}$ iso-activity curves of $\mathrm{FeO}$ at $1873 \mathrm{~K}$ in liquid $\mathrm{SiO}_{2}-\mathrm{FeO}-\mathrm{MgO}$ solution (liquid standard state).

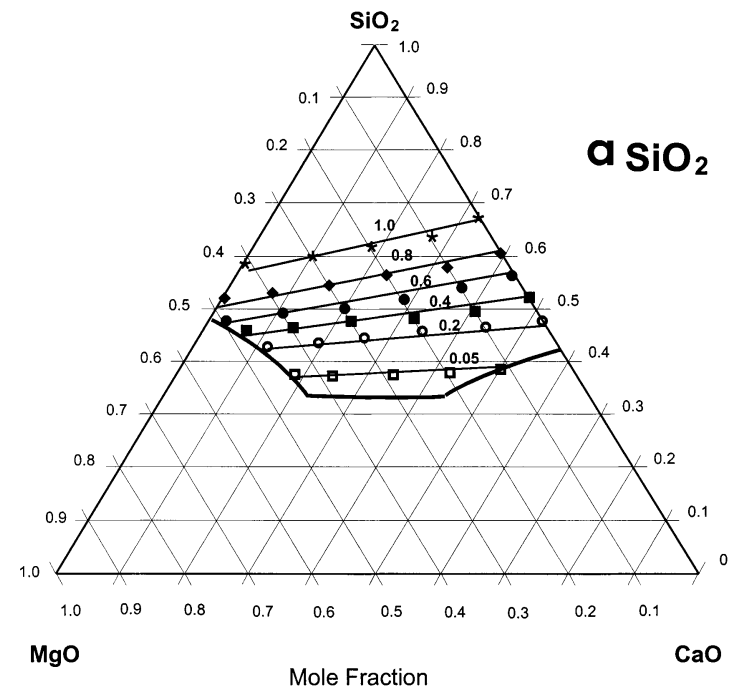

Fig. 3. Calculated and experimental ${ }^{8)}$ iso-activity curves of $\mathrm{SiO}_{2}$ at $1873 \mathrm{~K}$ in liquid $\mathrm{SiO}_{2}-\mathrm{MgO}-\mathrm{CaO}$ solution (solid standard state).

ing manganese oxide were brought into equilibrium with thin strips of platinum metal at controlled partial pressure of oxygen, obtained from mixtures of carbon dioxide, hydrogen and nitrogen. The Gibbs energy of fusion of pure $\mathrm{MnO}$ was taken as ${ }^{9)}$ :

$$
\Delta \mathrm{G}_{\text {fusion }}^{\circ}(\mathrm{MnO})=54392.0-25.71454 T \quad \mathrm{~J} / \mathrm{mol} \ldots
$$

\section{5. $\mathrm{SiO}_{2}-\mathrm{Na}_{2} \mathrm{O}-\mathrm{MgO}$}

The model has been also used to estimate the thermodynamic properties of ternary silicate systems with a monovalent cation in the silica rich region. The activities of $\mathrm{Na}_{2} \mathrm{O}$ were measured by Rego et al. ${ }^{11)}$ at $1673 \mathrm{~K}$ by a gas phase equilibration technique to generate $\mathrm{Na}_{2} \mathrm{O}$ isoactivity data at high-silica compositions in this system. The experimental and calculated activities of $\mathrm{Na}_{2} \mathrm{O}$ shown in Fig. 5 are in good agreement.

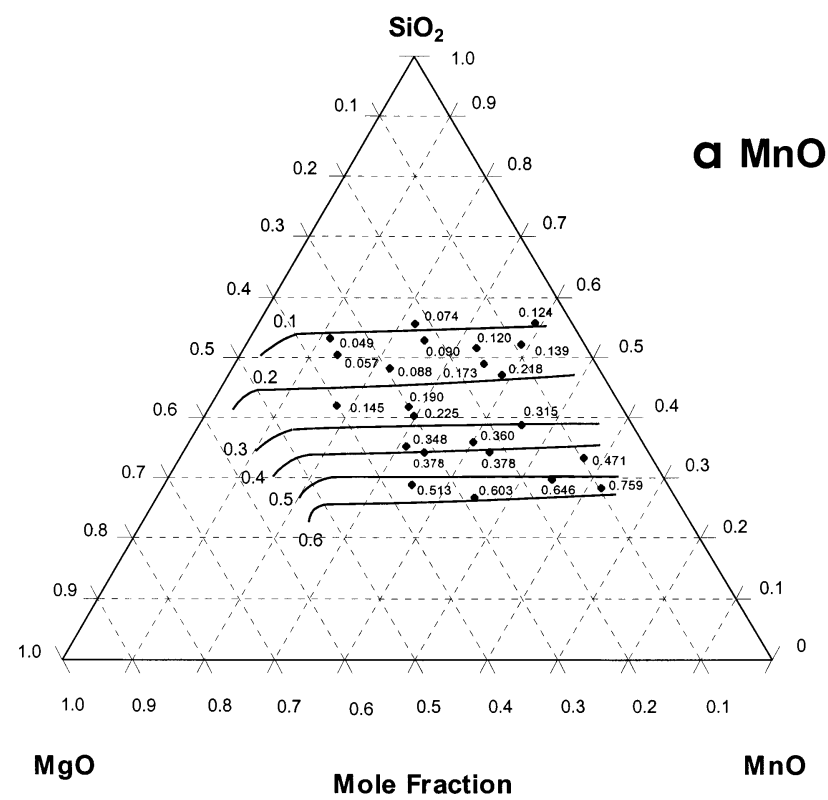

Fig. 4. Calculated and experimental ${ }^{10)}$ iso-activity curves of $\mathrm{MnO}$ at $1923 \mathrm{~K}$ in liquid $\mathrm{SiO}_{2}-\mathrm{MnO}-\mathrm{MgO}$ solution (solid standard state).

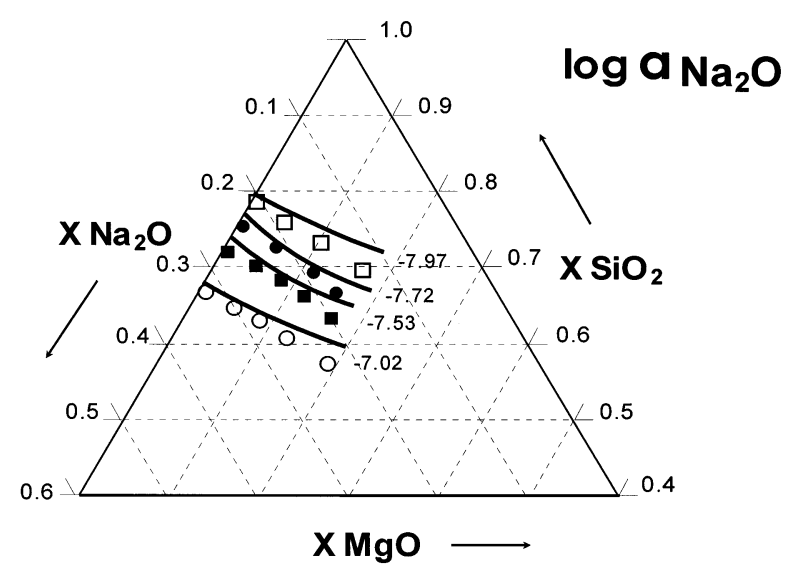

Fig. 5. Calculated and experimental ${ }^{11)}$ iso-activity curves of $\mathrm{Na}_{2} \mathrm{O}$ at $1673 \mathrm{~K}$ in liquid $\mathrm{SiO}_{2}-\mathrm{Na}_{2} \mathrm{O}-\mathrm{MgO}$ solution (liquid standard state).

\section{6. $\mathrm{SiO}_{2}-\mathrm{Na}_{2} \mathrm{O}-\mathrm{CaO}$}

The activities of $\mathrm{Na}_{2} \mathrm{O}$ were also measured by Rego et $a l^{11)}$ at $1673 \mathrm{~K}$ in the silica rich region of the $\mathrm{SiO}_{2}-\mathrm{Na}_{2} \mathrm{O}$ $\mathrm{CaO}$ system. The experimental and calculated activities of $\mathrm{Na}_{2} \mathrm{O}$ are shown in Fig. 6. Agreement is well within the uncertainties.

\section{Discussion}

The amount of different kind of oxygens in the $\mathrm{SiO}_{2}-$ $\mathrm{FeO}-\mathrm{CaO}$ predicted by the model at $1823 \mathrm{~K}$ and $X_{\mathrm{SiO}_{2}}=$ 0.35 is shown in Fig. 7. Although the experimental evidence is scarce it is clear that there is a complete breakdown of the polymeric structure by the $\mathrm{CaO}$ and $\mathrm{FeO}$ basic oxides at this composition of $\mathrm{SiO}_{2}$. This Figure also shows that the cations $\mathrm{Ca}^{2+}$ are associated to the $\mathrm{O}^{-}$and the amount of $\mathrm{O}_{\mathrm{Ca}}^{2-}$ is negligeable along all the composition range, whereas cations $\mathrm{Fe}^{2+}$ are partially associated to the $\mathrm{O}^{-}$especies and free oxygen ions $\mathrm{O}_{\mathrm{Fe}}^{2-}$. In this way the 


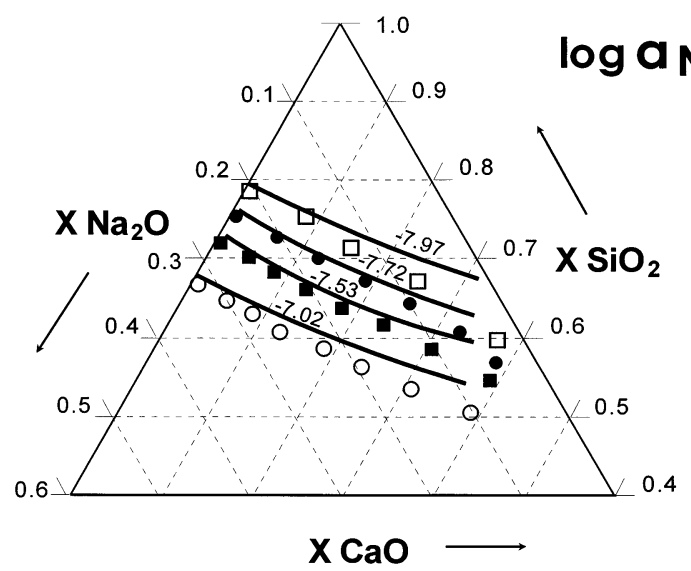

Fig. 6. Calculated and experimental ${ }^{11)}$ iso-activity curves of $\mathrm{Na}_{2} \mathrm{O}$ at $1673 \mathrm{~K}$ in liquid $\mathrm{SiO}_{2}-\mathrm{Na}_{2} \mathrm{O}-\mathrm{CaO}$ solution (liquid standard state).

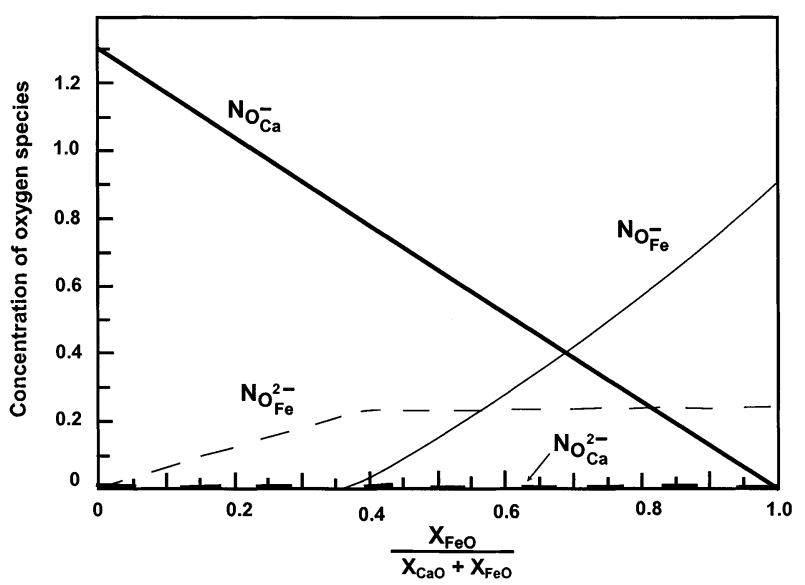

Fig. 7. Concentration of oxygen species in the $\mathrm{SiO}_{2}-\mathrm{FeO}-\mathrm{CaO}$ system calculated by the model at $1823 \mathrm{~K}$ and $\mathrm{X}_{\mathrm{SiO}_{2}}=$ 0.35 .

model takes into account the non random mixing of cations in the silicate structure.

The characteristic "c" shape of the $\mathrm{FeO}$ activity curves in the $\mathrm{SiO}_{2}-\mathrm{FeO}-\mathrm{CaO}$ system at $1823 \mathrm{~K}$, shown in Fig. 8, is explained by the amount of broken bridges $\left(\mathrm{O}_{\mathrm{Ca}}^{-}\right.$and $\left.\mathrm{O}_{\mathrm{Fe}}^{-}\right)$ produced by the bridge breaking reactions, Eqs. (14) and (15). The bold line separates the regions where the $\mathrm{FeO}$ contributes to the breaking oxygen bridges, i.e. where $N_{\mathrm{O}_{\mathrm{Fe}}^{-}}=0$ and $N_{\mathrm{O}_{\mathrm{Fe}}^{-}}>0$, which corresponds with the sharp change in the slope of the curves.

When extended to $\mathrm{SiO}_{2}-\mathrm{Na}-\mathrm{O}-\mathrm{MgO}$ and $\mathrm{SiO}_{2}-\mathrm{Na}_{2} \mathrm{O}-$ $\mathrm{CaO}$, the model gives a good representation of the thermodynamic data in the acid region $\left(X_{\mathrm{SiO}_{2}}>0.50\right)$. This supports to the assumption of the model, that in the silica rich region, two cations $\mathrm{Na}^{+}$are associated with each broken oxygen bridge.

\section{Conclusions}

The earlier structural model ${ }^{1,2)}$ for binary silicate melts has been extended to ternary systems for the representation of liquid silicate systems $\mathrm{SiO}_{2}-\mathrm{AO}-\mathrm{BO}$, where $\mathrm{A}$ and $\mathrm{B}$ are

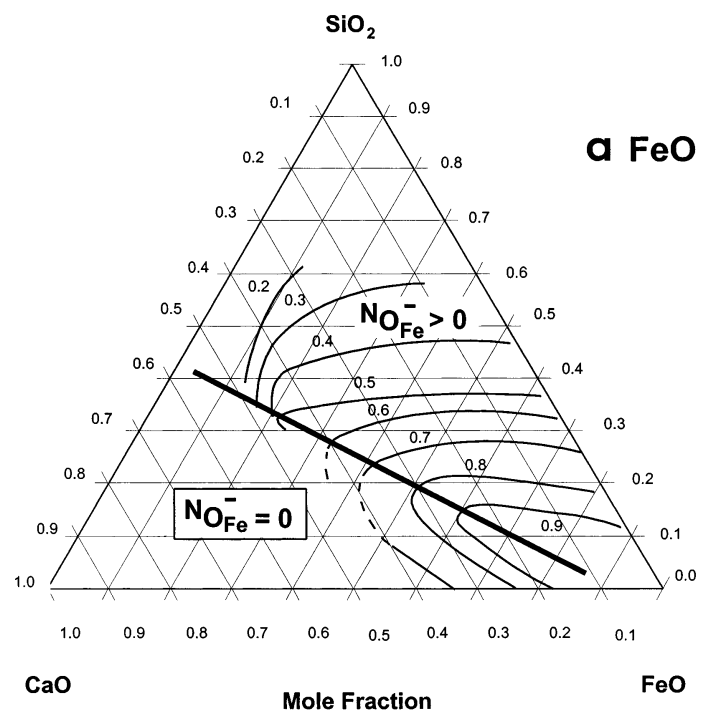

Fig. 8. Activities of $\mathrm{FeO}$ (liquid standard state) and range of concentration where the $\mathrm{FeO}$ contributes to the breaking oxygen bridges in the $\mathrm{SiO}_{2}-\mathrm{FeO}-\mathrm{CaO}$ system at $1823 \mathrm{~K}$.

metals such as $\mathrm{Ca}, \mathrm{Fe}, \mathrm{Mn}$, etc. The model assumes that each metallic oxide produces the depolymerization reaction $\mathrm{O}^{\circ}+\mathrm{O}^{2-}=2 \mathrm{O}^{-}$with a characteristic free energy change. The model can calculate the properties of ternary systems solely from data of the binary sub-systems. No ternary terms are required.

The model is used to calculate the activities of the components in complex silicates such as $\mathrm{SiO}_{2}-\mathrm{FeO}-\mathrm{CaO}$ where the behavior of $\mathrm{Fe}^{2+}$ is very different from that of $\mathrm{Ca}^{2+}$ in the silicate structure. This model has been also used to calculate the activities in the systems $\mathrm{SiO}_{2}-\mathrm{MgO}-\mathrm{FeO}, \mathrm{SiO}_{2}-$ $\mathrm{MgO}-\mathrm{CaO}, \mathrm{SiO}_{2}-\mathrm{MgO}-\mathrm{MnO}, \mathrm{SiO}_{2}-\mathrm{Na}_{2} \mathrm{O}-\mathrm{CaO}$ and $\mathrm{SiO}_{2}-$ $\mathrm{Na}_{2} \mathrm{O}-\mathrm{MgO}$. Good agreement is obtained between calculated and experimental results.

\section{Acknowledgements}

The authors wish to thank the Institutions CONACyT, SNI, COFAA and Instituto Politecnico Nacional for their permanent assistance to the Process Metallurgy Group at ESIQIE-Department of Metallurgy.

\section{REFERENCES}

1) P. L. Lin and A. D. Pelton: Metall. Trans. B, 10B (1979), 667.

2) A. Romero-Serrano and A. D. Pelton: Metall. Mater. Trans. B, 26B (1995), 305.

3) A. D. Pelton, G. Eriksson and A. Romero-Serrano: Metall. Trans. B, 24B (1992), 817.

4) A. Romero and A. D. Pelton: ISIJ Int., 39 (1999), 399

5) A. Romero-Serrano: Ph. D. Thesis, Ecole Polytechnique, Montreal, (1992).

6) M. Timucin and A. E. Morris.: Metall. Trans., 1 (1970), 3193.

7) S. Ban-ya, M. Hino and N. Yuge: Tetsu-to-Hagané, 73 (1987), 476.

8) R. H. Rein and J. Chipman: Trans. AIME, 233 (1965), 415.

9) I. Barin: Thermochemical Data of Pure Substances, VCH, Weinheim, (1989).

10) R. S. Metha and F. D. Richardson: J. Iron Steel Inst., 203 (1965), 524.

11) D. N. Rego, G. K. Sigworth and W.O. Philbrook: Metall. Trans. B, 19B (1988), 655. 